\title{
Can Disable Person be Transformed Positively?
}

\section{Zarina Abdul Salam, Lily Julienti Abu Bakar, Nur Naha Abu Mansor, Noor Afza Amran}

To Link this Article: http://dx.doi.org/10.6007/IJARAFMS/v11-i3/10924 DOI:10.6007/IJARAFMS/v11-i3/10924

Received: 20 July 2021, Revised: 23 August 2021, Accepted: 09 September 2021

Published Online: 27 September 2021

In-Text Citation: (Salam et al., 2021)

To Cite this Article: Salam, Z. A., Bakar, L. J. A., Mansor, N. N. A., \& Amran, N. A. (2021). Can Disable Person be Transformed Positively? International Journal of Academic Research in Accounting Finance and Management Sciences, 11(3), 457-464.

Copyright: $($ ) 2021 The Author(s)

Published by Human Resource Management Academic Research Society (www.hrmars.com)

This article is published under the Creative Commons Attribution (CC BY 4.0) license. Anyone may reproduce, distribute, translate and create derivative works of this article (for both commercial and non-commercial purposes), subject to full attribution to the original publication and authors. The full terms of this license may be seen at: http://creativecommons.org/licences/by/4.0/legalcode

Vol. 11, No. 3, 2021, Pg. 457 - 464

Full Terms \& Conditions of access and use can be found at http://hrmars.com/index.php/pages/detail/publication-ethics 


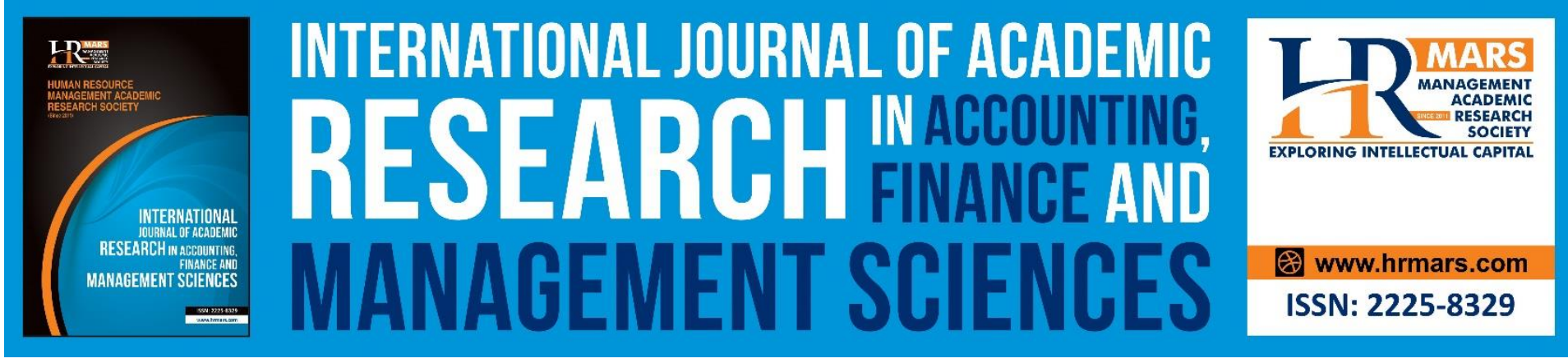

\title{
Can Disable Person be Transformed Positively?
}

\author{
Zarina Abdul Salam, Lily Julienti Abu Bakar, Nur Naha Abu \\ Mansor, Noor Afza Amran \\ University Technology Malaysia, University Utara Malaysia
}

\begin{abstract}
Historically, employment rate for disabled persons was low because the employers perceived them to be incompetent due to their inabilities to make decisions and incapable to work like a non-disable person. Disabled persons that were employed always being discriminated by the employers and co-workers. This study investigated ten disabled persons with different types of disabilities after attending a series of seminars with the intention to improve their skills and abilities which will hopefully assist them to work independently in the community and work place in the future. The data was collected qualitatively after all seminar sessions through observations and interviews with the participants, staffs handling the programme, volunteers, partners and corporates. This research found that disabled persons have higher level of confidence level after attending the seminars and they showed their intention to look for jobs in the future. They were also succeeded in completing the projects and tasks by working as a team and be cooperative without hassle. Their mindset had also improved positively by making decisions that were beyond the initial expectations. The corporate staffs were very amazed with the hidden abilities of disabled person and they are willing to hire these disabled persons in the work place. From these findings, it is recommended that the community change their unpleasant perceptions towards disable persons and corporates should trust and give opportunities to disabled person to show their capabilities and employ them permanently and not look down on them to perform their work.
\end{abstract}

Keywords: Disabled Person, Employment.

\section{Introduction}

The United Nations reported that the current world population as at August 2021 is 7.9 billion and according to the World Bank, around $15 \%$ of the world's population experience some form of disability. Disability is defined as a physical or mental condition that limits a person's movements, senses or activities. The International Classification of Functioning, Disability and Health (ICF) is a framework that provides a standard language and conceptual basis for the definition and measurement of health and disability. According to ICF, functioning and disability are a multi-dimensional concept that relates to (a) the body functions and structures of people and the impairments thereof, (b) the activities of the people including their limitations, (c) the participation of people in all areas of life including restrictions and lastly, (d) the environmental factors. In other words, ICF conceptualise functioning level of a person 
MANAGEMENT SCIENCES

Vol. 11, No. 3, 2021, E-ISSN: 2225-8329 @ 2021 HRMARS

based on integration of social and medical models which includes a person's interaction between his or her health conditions, environmental factors and personal factors.

Federal Constitution of Malaysia 1963 stated that all persons are equal before the law and are entitled to the equal protection of the law. There shall be no discrimination against citizens, regardless of religion, race, descent, gender, etc. Disable persons are also a part of the community. They have the right to live as other members of society. However, in reality, disabled persons are being discriminated to be employed (Lindsay, 2011; Lessy et al., 2021) due to several factors or barriers which are age, type and severe of disabilities, education level and socio-demographic factors such as geographic location or distance from the workplace. According to Article 1 of the United Nations Convention on the Rights of Person with Disabilities, disabled people have long term physical, mental, intellectual or sensory impairments of which may hinder their full and effective participation in society on an equal basis with others. Therefore, how can we assist the disable person to have the feeling of same rights and opportunities with non-disable person? How can we assist the disable person to manage themselves and increase their confidence level in doing their work? How can we assure the corporate world to have confidence in disabled persons and recruit them and provide jobs based on their ability? Theoretically, if moral support and motivations are given to the disabled persons, they can definitely be independent and manage to survive on their own. Based on these questions, this research is conducted to investigate the disabled person after additional supports were provided to them and see the changes or outcomes afterwards.

\section{Literature Review}

United Nations reported that unemployment rate for person with disabilities was $26 \%$ which was five times higher than the $5 \%$ rate of person without disabilities. The World Health Organization estimated that around 600 million disabled were looking for employment in 2005 but $80 \%$ to $90 \%$ of these disabled persons were unemployed and in industrialized countries, the percentage were between $50 \%$ to $70 \%$. Disabled persons faced many difficulties such as discrimination and unemployment (Konrad et al., 2013) and job insecurity (Cunningham, James and Dibben, 2004). Therefore, the Americans with Disabilities Act was introduced in 1990 to pave ways for disabilities to be employed.

Disabled persons faced numerous challenges in the workplace if they are being employed. The issues arise due to some factors such as specific disability of the person, biasness from employers and co-workers' attitudes. Specific disability of the person comprised of lack of education where less than $20 \%$ had a degree, difficulty with transportation as some were using wheelchair to move around, trapped in poverty and they couldn't dress well to impress the communities and advancing age because some person become disabled with increasing age (Mellinger, 2019).

Biasness from employers and communities is one of the main factors that disabled persons are facing currently. Employing disabled person helped in creating more positive working environment but the managers were still biased against hiring working with disabilities (Hernandez et al., 2008). Kaye (2009) investigated 269 disabled employees to understand why people with disabilities hold lower status in the workplace and why they were being less 
MANAGEMENT SCIENCES

Vol. 11, No. 3, 2021, E-ISSN: 2225-8329 @ 2021 HRMARS

remunerated as compared to non-disable persons. The possible reasons were employer discrimination, deficits in relevant skills or experience and work disincentives.

Barbra and Mutswanga (2014) investigated the attitude of employers and co-workers towards disabilities employees of Chitungwa in Zimbabwe qualitatively. Thirty participants were selected of which consists of ten employers, ten co-workers and ten disability employees. The employees with disabilities were discriminated by the employers and co-workers. The employers viewed that the person with disabilities scared away their customers, lacking knowledge and have poor qualifications to be employed. The co-workers perceived disabled person as incompetent because they need the assistance of the fellow workers to accomplish their tasks. The co-workers think that the employees with disabilities need maximum supervision and the assigned task must be selective and suitable for their disability conditions. However, Kumar, Srivastava and Singh (2019) found that the co-workers regardless of gender were not discriminating the disabled employees because the disable employees were very friendly, sociable and job oriented.

An American company Walgreens opened a centre with $30 \%$ disabled employees and surprisingly this centre is $20 \%$ more efficient than a centre without disabilities (Kaletta et al., 2012). Kumar, Srivastava and Singh (2019) found that disabled employees had positive attitudes and mixed well with non-disabled employees. Therefore, this study is conducted to investigate whether the disabled persons can be transformed positively if they are equipped with sufficient training, will they manage to accomplish their tasks without assistance and will they be employed by the corporate world that allow them to be independent in the future?

\section{Methodology}

Persatuan Orang-orang Cacat Anggota Malaysia (POCAM) was formed in 1976 by the disabled persons with the main objectives to (a) bring the spirit among its members; (b) improve their physical, special and economic conditions, (c) assist in education, training, employment and resettlement in society; and (d) organize sports, social and events for the benefits of disabled person. There are around one thousand members currently and the number should be increased as the disabled persons might need support from Malaysian non-disabled persons. As the number registered with POCAM is very few, this research found that it was very difficult to find the sample with homogeneous characteristics. The process of finding and selecting the disabled person as the sample and meet the criteria of program took three months to complete. This research identified the sample with less obvious disabilities because many disabled persons have less confidence to put themselves at the same level of non-disabled person and this will also to ensure that this program will be successful before further research is made for more severe disabilities persons.

Ten disabled persons with various background were selected from Department of Social Welfare, Children's Home and Special Education Schools around Kedah and Perak. Three of the samples were undergraduate with good level of education and the remaining samples only have a high school certificate. The details of the sample chosen were as follows: 
INTERNATIONAL JOURNAL OF ACADEMIC RESEARCH IN ACCOUNTING, FINANCE AND

MANAGEMENT SCIENCES

Vol. 11, No. 3, 2021, E-ISSN: 2225-8329 @ 2021 HRMARS

\begin{tabular}{|c|c|c|c|c|}
\hline NO & GENDER & AGE & EDUCATION LEVEL & TYPE OF DISABILITY \\
\hline 1 & Male & 21 & Secondary school & Slow learner \\
\hline 2 & Male & 22 & Secondary school & Slow learner \\
\hline 3 & Male & 20 & $\begin{array}{c}\text { Lower Secondary Evaluation } \\
\text { Lower Secondary Evaluation \& IT } \\
\text { Certificate for people with eye disability }\end{array}$ & Visual impairment \\
\hline 4 & Male & 27 & Bachelor in Public Management & $\begin{array}{c}\text { Physical - } \\
\text { hand and leg }\end{array}$ \\
\hline 5 & Male & 23 & Malaysian Certificate Examination & Slow learner \\
\hline 6 & Male & 24 & Malaysian Certificate Examination & Physical - hand \\
\hline 7 & Male & 26 & Bachelor in Decision Science & Physical - hand \\
\hline 8 & Female & 22 & Bachelor in Marketing & Speech disability \\
\hline 9 & Female & 22 & Secondary school & Slow learner \\
\hline 10 & Female & 20 & &
\end{tabular}

An intensive training was conducted through a series of seminars for the disabled persons which includes motivational session, entrepreneurial mind-set, communication and computing, interpretation skills, tourism and survival in the woods. These trainings were conducted in six months for the disabled persons who have different visual, learning and physical abilities. In order to bridge the gap, apart from moderators and facilitators, three undergraduate disabled persons with learning abilities were asked to assist those without learning disabilities in an informal way to make them understand throughout the learning process. This approach greatly made the other seven samples to feel more comfortable, contented and relaxed and make them happy to join the program from the beginning till the end. However, there were also times where certain disabled person were difficult to follow what had been taught during the seminars. Nevertheless, all sample were very happy and satisfied with what they have learnt in the end.

Several companies were invited during the seminars to assist and informed the disabled persons about the current industry requirements and how to optimize productivity. The corporate staffs were very supportive and also provide materials for the seminars. These companies were interviewed after the session to know their opinion on disabled persons' ability to do jobs in the workplace and their acceptance to hire these disabled persons in the future.

Logic Models (Kellog Foundation, 2000) is a program planning tool that defines the inputs, outputs and outcomes of a program in order to explain the thinking behind the program that had been designed and show how specific program activities lead to the desired results. Inputs include the resources, contributions, investments that go into a program; outputs are the activities, services, events and products that reach the participants and outcomes are the results or changes related to the program intervention that are experienced by the participants. Logic Model was used to see the relationship among the resources, activities, output and outcomes of this training program that had been conducted. The outcomes gained were by observations and interviewing the participants, staff handling the programme, volunteers, partners and corporates after all seminar sessions. 


\begin{tabular}{|c|c|c|c|c|c|}
\hline \multirow[t]{2}{*}{ INPUTS } & \multicolumn{2}{|c|}{ OUTPUTS } & \multicolumn{3}{|c|}{ OUTCOMES } \\
\hline & Activities & Participation & Short Term & Medium Term & Long Term \\
\hline
\end{tabular}

\section{Data Analysis}

Logic model was used to identify the input, output and outcome of the seminars conducted for the selected disabled persons. The inputs are referred to the things that this study invest which are staff, volunteers, time, money, materials, equipment, technology and partners. The outputs are divided into two categories which are activities and participation. The activities conducted were a series of seminars which includes motivational session, entrepreneurial mind-set, communication and computing, interpretation skills, tourism and survival in the woods. The participation consists of ten disabled person with different disabilities and corporates. The outcomes are the changes or outcomes resulted from the activities that had been conducted. The outcomes are divided into three categories which are short term, medium term and long-term results as follows:

\begin{tabular}{|c|c|c|c|c|c|}
\hline \multirow[t]{2}{*}{ INPUTS } & \multicolumn{2}{|c|}{ OUTPUTS } & \multicolumn{3}{|c|}{ OUTCOMES } \\
\hline & Activities & rticipation & Short Term & Medium Term & Long Term \\
\hline $\begin{array}{l}\text { What we } \\
\text { invest? } \\
\text { - staff } \\
\text { - volunteers } \\
\text { - time } \\
\text { - money } \\
\text { - materials } \\
\text { - equipment } \\
\text { - technology } \\
\text { - partners. }\end{array}$ & $\begin{array}{l}\text { What we do? } \\
\text { A series of } \\
\text { Seminars } \\
\text { - motivational } \\
\text { session } \\
\text { - entrepreneurial } \\
\text { mind-set } \\
\text { - communication } \\
\text { and computing } \\
\text { - interpretation } \\
\text { skills } \\
\text { - tourism } \\
\text { - survival in the } \\
\text { woods }\end{array}$ & $\begin{array}{l}\text { Who we } \\
\text { reach? } \\
\text { - Disabled } \\
\text { person } \\
\text { - Corporate }\end{array}$ & $\begin{array}{l}\text { What are the } \\
\text { short-term } \\
\text { results? } \\
\text { - Confident } \\
\text { level } \\
\text { - Teamwork } \\
\text { - Positive mid } \\
\text { set } \\
\text { - Industry } \\
\text { awareness } \\
\text { - Industry } \\
\text { acceptance }\end{array}$ & $\begin{array}{l}\text { What are the } \\
\text { medium-term } \\
\text { results? } \\
\text { - Parents and } \\
\text { guardian } \\
\text { satisfaction }\end{array}$ & $\begin{array}{l}\text { What are the } \\
\text { long term } \\
\text { results? } \\
\text { - Evaluation of } \\
\text { disabled } \\
\text { persons } \\
\text { - Program } \\
\text { improvement } \\
\text { for the future }\end{array}$ \\
\hline
\end{tabular}

\section{Short Term Outcomes}

People with disability faced numerous challenges in the community because of their conditions. Some of the communities look down on them and believed that they cannot do tasks as a non-disable person. Due to the community perspectives, the disabled person lost their confidence level and think of themselves as useless and unproductive. After the seminars were conducted, this research found that in the short term, the disabled persons have higher level of confidence level because the seminars had equipped them with additional knowledge and skills for them to be independent and useful for the future. The disabled persons had shown their improvement by having the intention to look for jobs in the future.

Apart from improvement in confidence level, the disabled person also showed greater improvement in teamwork. Exercises or projects were given to enhance their abilities to do 
MANAGEMENT SCIENCES

Vol. 11, No. 3, 2021, E-ISSN: 2225-8329 @ 2021 HRMARS

several tasks in a team. Initially, some of the disabled persons showed their reluctance to do the tasks but the encouragement by the facilitators and disabled persons who showed their eagerness to do the projects successfully showed their inclination to finish off the tasks towards the end. Those who were very hesitant to do the work were due to their low confidence level of which managed to be improved after the session(s). Surprisingly, all disabled persons were very happy with their work in the end and they were looking for more exercises afterwards.

Working in a team also enhanced the mindset of the disabled person to be entrepreneurial and independent in making their decisions. All disabled persons managed to throw out the ideas how to be a successful entrepreneur despite their disabled conditions. There were many good suggestions shared by the disabled persons which were beyond expectations. However, conflicts also aroused because they have different views on how to solve problems. The speakers and facilitators taught them how to cooperate and make the best decisions that will favor all and not based on an individual preference. The disabled persons learnt how to manage any failures and that will motivate them to be more matured in reality.

The industry's awareness was more visible after the program because the companies that were invited were willing to join in more corporate social responsibility activities in the future. They were very impressed of the hidden abilities of disabled person to do the work because they had higher focus and responsibility to finish off their work. These disabled persons had untapped sources of skills and talents that can be used in the workplace.

The industry's acceptance to hire disabled person was higher after they had seen the disabled persons did the complete exercises and projects successfully. Hiring disabled person will contribute to the overall diversity, creativity and workplace morale and enhance the company's reputation among its staff, community and customers. Employees with disabilities worked harder, more productive, more loyal and lower absenteeism rate (Hernandez et al., 2008).

\section{a) Medium Term Outcomes}

Parents or guardians were interviewed before and after the seminars in order to know the changes of disabled persons in terms of their behaviours and attitudes. All parents and guardians were incredibly delighted with the outcomes of the seminars because these disabled persons had developed positive behaviours and attitudes such as more determined, independent, creative in solving problems and making decisions, inventive, kind, caring and loving, outgoing and knowledgeable. The parents and guardians were looking for more seminars and training for the disabled persons in the future.

\section{Conclusion}

Disable persons should be treated equally and not being discriminated because they were born with that condition from birth or after birth due to injuries. Non-disable persons should change their perspectives towards the disable persons positively because otherwise, disable persons will continue to rely on other people for their livelihoods. The seminars had indeed transformed the disabled persons to be more positive and skillful in managing their life. The evidences strongly proven that the disable persons have higher confidence level to apply jobs in the corporate world if a strong support and motivations are provided by the non-disable community. The disable persons had high commitments to the given tasks. The companies that were invited were very confident with the capabilities of the disabled persons and they were ready to employ these disabled persons instantaneously. 
MANAGEMENT SCIENCES

Vol. 11, No. 3, 2021, E-ISSN: 2225-8329 @ 2021 HRMARS

The findings suggested that the disabled persons can work if the community encourage or motivate them to increase their spirit of confidence level. A study on evaluation of these disabled person in the workplace should be conducted in the future and this will be considered as long-term outcomes. Apart from that, evaluation of the seminars should also be placed in order to improve the outcomes to the disabled persons. These seminars program will contribute to the society by improving the knowledge and attitudes of the disabled persons in reality and encourage them to be more independent by having the confidence level to work side by side with non-disabled persons in community and don't feel humiliated towards their disabilities.

\section{References}

Cunningham, I., James, P., \& Dibben, P. (2004). Bridging the gap between rhetoric and reality: Line managers and the protection of job security for ill workers in the modern workplace. British Journal of Management, 15(3), 273-290.

Hernandez, B., Mc Donald, K., Divilbiss, M., Horin, E., Velcoff, J., \& Donoso, O. (2008). Reflections from employers on the disabled workforce: Focus groups with healthcare, hospitality and retail administrators. Employee Responsibilities and Rights Journal, 20, 157-164.

Kaletta, J. P., Binks, D. J., \& Robinson, R. (2012). Creating an inclusive workplace: Integrating employees with disabilities into a distribution center environment. Professional Safety, $57,62-71$.

Kaye, H. S. (2009). Stuck at the bottom rung: Occupational characteristics of workers with disabilities. Journal of Occupational Rehabilitation, 19, 115.

Konrad, A. M., Moore, M. E., Ng, E. S. W., Doherty, A. J., \& Breward, K. (2013). Temporary work, underemployment and workplace accommodations: Relationship to well-being for workers with disabilities. British Journal of Management, 24(3), 367-382.

Kumar, A., Srivasta, S. K., \& Singh, K. (2019). Study on attitude of co-workers towards employees with intellectual disabilities. Indian Journal of Public Health Research and Development, 10(12), 720-724.

Lindsay, S. (2011). Discrimination and other barriers to employment for teens and young adults with disabilities. Disability and Rehabilitation, 33(15-16), 1340-1350.

Lessy, Z., Kailani, N., \& Jahidin, A. (2021). Barriers to employment as experienced by disabled university graduates in Yogyakarta, Indonesia. Asian Social Work and Policy Review, 15(2), 133-144.

Mapuranga, B., \& Mutswanga, P. (2014). The attitudes of employers and co-workers towards the employment of persons with disabilities in Zimbabwe. International Journal of Managerial Studies and Research, 2(3), 7-19

Mellinger, B. B. (2019). The disadvantages of disabled persons in the workplace. Chron. https://smallbusiness.chron.com/disadvantages-disabled-persons-workplace13485.html 